\title{
Genetic and Clinical Characteristics of Patients with Vitamin D Dependent Rickets Type $1 \mathrm{~A}$
}

\author{
(D) Fatma Dursun1, (D) Gamze Özgürhan2 , (D) Heves Kırmızıbekmez¹, (D) Ece Keskin³, (D) Bülent Hacıhamdioğlu4 \\ 1 Ümraniye Training and Research Hospital, Clinic of Pediatric Endocrinology, Istanbul, Turkey \\ 2Süleymaniye Maternity and Children's Training and Research Hospital, Clinic of Paediatrics, Istanbul, Turkey \\ 3Süleymaniye Maternity and Children's Training and Research Hospital, Clinic of Medical Genetic, Istanbul, Turkey \\ 4 istinye University Faculty of Medicine, Department of Pediatric Endocrinology, Istanbul, Turkey
}

\begin{abstract}
What is already known on this topic?
Although vitamin D dependent rickets type 1A (VDDR1A) is a rare disease, it is relatively more common in Turkey. Thus far intron-1 mutations have only been reported from Turkey. Intron-1 mutations have been reported to be associated with milder clinical findings. Clinical and laboratory findings can overlap with other types of rickets. Serum 1,25-dihydroxyvitamin D levels are usually reported to be low in cases of VDDR1A.
\end{abstract}

\section{What this study adds?}

Patients with intron-1 mutations can present with clinical findings of variable severity. We also found that the concentrations of 1,25-dihydroxyvitamin $\mathrm{D}$ levels may be within inappropriately normal ranges in genetically proven vitamin D dependent rickets type $1 \mathrm{~A}$ and lead to diagnostic confusion.

\section{Abstract}

Objective: Vitamin D dependent rickets type 1 A (VDDR1 A) is an autosomal recessive disorder caused by mutations in the $1 \alpha$-hydroxylase gene (CYB27B1). As it may be confused with nutritional rickets and hypophosphatemic rickets, genetic analysis is important for making a correct diagnosis.

Methods: We analysed genomic DNA from 11 patients from eight different Turkish families. The patients were recruited for our studies if they presented with a diagnosis of VDDR.

Results: The mean \pm standard deviation age at diagnosis was 13.1 \pm 7.4 months. Seven patients had mild hypocalcemia at presentation while four patients had normal calcium concentrations. All patients underwent CYP27B1 gene analysis. The most prevalent mutation was the c. $195+2 \mathrm{~T}>\mathrm{G}$ splice donor site mutation, affecting five out of 11 patients with VDDR1A. Two patients from the fourth family were compound heterozygous for c. $195+2 \mathrm{~T}>\mathrm{G}$ and c. $195+2 \mathrm{~T}>\mathrm{A}$ in intron-1. Two patients, from different families, were homozygous for a previously reported duplication mutation in exon 8 (1319_1325dupCCCACCC, Phe443Profs*24). One patient had a homozygous splice site mutation in intron 7 (c.1215 $+2 \mathrm{~T}>\mathrm{A}$ ) and one patient had a homozygous mutation in exon 9 (c.1474 C > T).

Conclusion: Intron-1 mutation was the most common mutation, as previously reported. All patients carrying that mutation were from same city of origin suggesting a "founder" or a "common ancestor" effect. VDDR1 A should definitely be considered when a patient with signs of rickets has a normal 25-OHD level or when there is unresponsiveness to vitamin D treatment.

Keywords: Vitamin D, vitamin D dependent rickets, CYP27B1 gene, $1 \alpha$ hydroxylase

Address for Correspondence: Fatma Dursun MD, Ümraniye Training and Research Hospital,

Clinic of Pediatric Endocrinology, İstanbul, Turkey

Phone: + 905052671403 E-mail: fatmadursun54@yahoo.com ORCID ID: orcid.org/0000-0003-4880-8175

${ }^{\circ}$ Copyright 2019 by Turkish Pediatric Endocrinology and Diabetes Society

The Journal of Clinical Research in Pediatric Endocrinology published by Galenos Publishing House.
Conflict of interest: None declared Received: 07.05.2018 Accepted: 03.10.2018 


\section{Introduction}

Vitamin D (calciferol) comprises two biologically inactive, fatsoluble pro-hormones. The first is ergocalciferol (vitamin D2), derived from ergosterol after ultraviolet (UV) light exposure and the second is cholecalciferol (vitamin D3), derived from animal tissues and 7-dehydrocholesterol, formed in human skin by the action of UV rays in sunlight (1). Both forms need a two-step hydroxylation at the $25^{\text {th }}$ and $1^{\text {st }}$ carbons for activation. The first step occurs in the liver, where vitamin $\mathrm{D}$ is hydroxylated to 25-hydroxyvitamin D (25-OHD) by hepatic 25-hydroxylase. The second step occurs mainly in the kidney, where 25-OHD is further hydroxylated by the mitochondrial vitamin D $1 \alpha$-hydroxylase to the biologically active hormone 1,25-dihydroxyvitamin D (1,25- $\left.\mathrm{OH}_{2} \mathrm{D}\right)$, which binds to its nuclear receptor and exerts its biological activities $(1,2,3)$. The biologically active $1,25-\mathrm{OH}_{2} \mathrm{D}$ plays a central role in calcium homeostasis and bone metabolism and also has a significant influence on cell proliferation and differentiation of a variety of tissues $(1,3,4)$. The renal synthesis of $1,25-\mathrm{OH}_{2} \mathrm{D}$ from its precursor $25-\mathrm{OHD}$ is a rate-limiting step and is tightly regulated by exisiting serum concentrations of $1,25-\mathrm{OH}_{2} \mathrm{D}$, parathyroid hormone (PTH), fibroblast growth factor-23 (FGF-23), calcium and phosphate concentrations, with renal $1 \alpha$-hydroxylase being stimulated by PTH, hypophosphatemia, or hypocalcaemia and inhibited by FGF-23 (4).

Four rare genetic errors of vitamin D metabolism that can cause rickets have been described. The first one involves $1 \alpha$-hydroxylase deficiency, which is also described as vitamin D dependent rickets type 1A (VDDR1A). A selective mutation in CYP2R1 gene, which leads to 25-hydroxylase deficiency, is called type 1B (VDDR1B). This second type involves a defective vitamin $\mathrm{D}$ receptor (VDR), resulting in vitamin $\mathrm{D}$ resistant rickets (VDRR), also known as VDDR type 2A (VDDR2A). VDDR2B is an unusual form of rickets due to abnormal expression of a hormone response elementbinding protein that interferes with normal function of VDR $(5,6,7,8)$.

VDDR1A is an autosomal recessive disorder caused by mutations in the 25-OHD $1 \alpha$-hydroxylase gene (CYB27B1). CYB27B1 is composed of nine exons and is approximately $5 \mathrm{Mb}$ in size. The gene has been mapped to the chromosomal region 12q14.1 (9,10,11,12). Clinically, VDDR1A is characterized by hypotonia, muscle weakness, inability to walk, growth failure and radiographic findings of rickets. Typical laboratory findings are hypocalcaemia, elevated serum levels of alkaline phosphatase (ALP) and of PTH with low or normal levels of $1,25-\mathrm{OH}_{2} \mathrm{D}$ despite normal or increased concentrations of 25-OHD $(9,13)$.
Patients with VDDR1 may present with aminoaciduria and hyperchloremic acidosis (3).

To date, over 100 patients with 78 mutations have been identified in the CYP27B1 gene in patients from multiple ethnic groups. These mutations span all exons of the gene and mostly include missense and nonsense changes, along with splice site changes, insertions, deletions and duplications [Human Gene Mutation Database (HGMD), http://www.hgmd.cf.ac.uk/ac/index.php] (14). Mutations in CYP27B1 lead to a loss of $1 \alpha$-hydroxylase activity and require treatment with calcitriol to normalize the clinical and laboratory abnormalities (15).

In the present study, we report 11 patients with VDDR1A from eight unrelated Turkish families. The most prevalent mutation was the c. $195+2 \mathrm{~T}>\mathrm{G}$ splice donor site mutation, affecting five out of 11 patients with VDDR1A. Clinical findings of patients were examined in detail and genotypephenotype correlations were evaluated.

\section{Methods}

We analyzed genomic DNA in 11 patients from eight different Turkish families. In five of these families, the parents were consanguineous. The study was approved by the University of Health Sciences Ümraniye Training and Research Hospital Clinical Research Ethical Committee (approved number: 19/01/2018-2926). Informed consent was obtained from patients and/or families.

Eleven patients had the clinical findings of rickets including X-bain deformity or bowed leg, chest rosary, Harrison's groove, frontal bossing, widening of the wrist, growth retardation, hypotonia and inability to walk together with hypocalcaemic seizures. The patients also had biochemical features suggestive of rickets such as hypophosphatemia, hypo- or normocalcemia, elevated PTH and ALP, normal or high 25-OHD levels and low or normal $1,25-\mathrm{OH}_{2} \mathrm{D}$ levels. Wrist and knee radiographs of all patients demonstrated widened epiphyses and metaphyseal cupping and fraying. Differentiation of nutritional rickets and VDDR1A was made by normal/high 25-OHD levels, low/inappropriately normal $1,25-\mathrm{OH}_{2}$ D levels and improvement in the clinical, biochemical and radiological findings of rickets after replacement with calcitriol. All patients received calcitriol and patients with hypocalcaemia received calcium replacement. Calcitriol was started at a dose of $1-1.5 \mathrm{mcg} /$ day, twice daily. Subsequently the calcitriol dose was titrated according to the results of biochemical analyses. The aims of the treatment were to achieve normocalcemia, to maintain PTH levels within normal limits and to avoid hypercalciuria. 


\section{Targeted Second Generation Sequence Analysis}

DNA was isolated from a 200 microlitre peripheral blood sample using QIAamp DNA Blood Mini QIAcube Kit and QIAcube device (QIAGEN, Hilden, Germany). Then, the exons of the CYP27B1 gene were amplified for targeted sequencing. Amplification was controlled with agarose gel electrophoresis technique. Sequencing was carried out using Illumina MiSeq NGS System (Illumina Inc., San Diego, CA, USA) and the Miseq Reagent Kit V3 (600 cycles) from the same manufacturer. The readings were aligned with human genome 19 genomic sequence and compared.

\section{Sanger Sequencing}

$10 \mathrm{~mL}$ venous blood sample was taken from each patient into EDTA tubes. DNA isolation was performed using the QIAamp DNA Mini QIAcube Kit from the peripheral blood. The Primer design included CYP27B1 gene exons and close introns (Table 1). The products of polymerase chain reaction (PCR) $\left[94^{\circ} \mathrm{C}-5 \mathrm{~min}\left(95^{\circ} \mathrm{C}-30 \mathrm{sec}-60^{\circ} \mathrm{C}-30 \mathrm{sec}-72{ }^{\circ} \mathrm{C}\right.\right.$ $\left.30 \mathrm{sec}) \times 34,72{ }^{\circ} \mathrm{C}-5 \mathrm{~min}\right]$ with the primers, also shown in Table 1, were checked on a $2 \%$ agarose gel. After the amplification of correct gene regions, purification of PCR products was made by maintenance for 15 minutes at 37 ${ }^{\circ} \mathrm{C}$ (enzyme activation temperature) and 15 minutes at 80 ${ }^{\circ} \mathrm{C}$ (enzyme inactivation temperature) in the thermal cycler using ExoSAP enzyme. After purification, the primer and the cleaned template DNA were added to the PCR solution, using "The Big Dye Ready Reaction Mix Sequencing Kit" (Applied Biosystems ${ }^{\circledR}$ Big Dye ${ }^{\circledR}$, Foster City, Calif., USA) and the PCR reaction was started. The purification process was repeated after the PCR sequencing for the removal of

\begin{tabular}{ll}
\hline $\begin{array}{l}\text { Table 1. List of primers used for polymerase chain } \\
\text { reaction amplification of the nine coding exons of } \\
\text { CYP27B1 gene }\end{array}$ \\
\hline Primer name & Primer sequence \\
\hline CYP27B1_1F: & GTCATCACCTCACCCAAAGG \\
CYP27B1_1R: & TCTGACGCTGTCAAAACCAG \\
CYP27B1_2F: & GAAGCTCCCTATTCCCAAGC \\
CYP27B1_2R: & CATGCCCCCAGATTGATAGT \\
CYP27B1_3-4F: & CTCCTTCACTGCAGCCAGTC \\
CYP27B1_3-4R: & GTGGGTAGAAGGCACGTGAA \\
CYP27B1_5F: & GCATTTGGTAAGGCACAGGT \\
CYP27B1_5R: & CATAATGGATCCCCTGCAAC \\
CYP27B1_6-7F: & CCATAATCTGCACCCTCTGC \\
CYP27B1_6-7R: & GGGCCCAAGATAGTGAGGA \\
CYP27B1_8F: & TCTTCATGCCTGCCCTATTC \\
CYP27B1_8R: & CAGGGGAAAGAGCTCACAAC \\
CYP27B1_9F: & CACCCAATCATTGACCATTC \\
CYP27B1_9R: & CATACTTCACACATTGGTCAGG \\
\hline
\end{tabular}

uncoupled dideoxynucleotide triphosphates in the solution. Sanger sequencing of the purified samples was performed on the ABI 3130 XL (Applied Biosystems ${ }^{\circledR} 3130$ Genetic Analyzers, Foster City, Calif., USA) capillary sequencing device. The obtained data were analysed by Applied Biosystems SeqScape ${ }^{\circledR}$ Software (Calif., USA) analysis program.

\section{Data Analysis}

Sequenced data were analyzed with the Genomize Variant Analysis Program (NHLBI GO Exome Sequencing Project, Seattle, USA) and Integrative Genomics Viewer (1000 Genomes Project, Calif., USA). The homozygote or compound heterozygote variants in the databases such as National Center for Biotechnology Information, HGMD, and Clinvar were primarily selected for data filtering. The effects of mutations on protein structures were tested with various in silico prediction tools, particularly Mutation Taster (16), PolyPhen-2 (17), and Sorting Tolerant From Intolerant (18).

\section{Statistical Analysis}

Statistical analysis was performed using IBM SPSS 21.0 for windows statistical software (IBM Inc., Chicago, Ill., USA). The data were presented as mean \pm standard deviation (SD) (ranges).

\section{Results}

Among patients diagnosed with VDRR1 A, six were males and five were females, from eight families. Clinical presentation and laboratory findings of the patients are summarized in Table 2. The mean age at diagnosis was $13.1 \pm 7.4$ months. Seven patients had mild hypocalcemia at presentation while four patients had normal calcium levels. Five of eight families had consanguineous marriages. The two families that were not consanguineous were from the same city.

All patients had clinical and laboratory features of rickets at the time of diagnosis. All patients had low levels of phosphorus with quite high levels of PTH and ALP levels (see Table 2). Five patients had fairly high levels of 25-OHD due to being formerly diagnosed with nutritional rickets and treated with vitamin D. Levels of $1,25-\mathrm{OH}_{2} \mathrm{D}$, on the other hand, were normal in three patients. One patient was previously followed for hypophosphatemic rickets and treated with calcitriol and phosphate. When he was diagnosed with VDDR1A, he had elevated PTH levels and typical radiological findings of rickets (Figure 1).

After the definitive diagnosis of VDDR1A all patients received calcitriol treatment. The duration of treatment with calcitriol ranged between six months and seven years. 
Biochemical improvement with treatment occurred within a period ranging between four and 12 months.

All patients underwent CYP27B1 gene analysis (Table 3). The most prevalent mutation was the c. $195+2 \mathrm{~T}>\mathrm{G}$ splice donor site homozygous mutation, affecting five out of 11 patients with VDDR1A. Two patients from family-4 had a compound heterozygous mutation for c. $195+2 \mathrm{~T}>\mathrm{G}$ and c.195 + 2 T > A in intron-1. Two patients from different
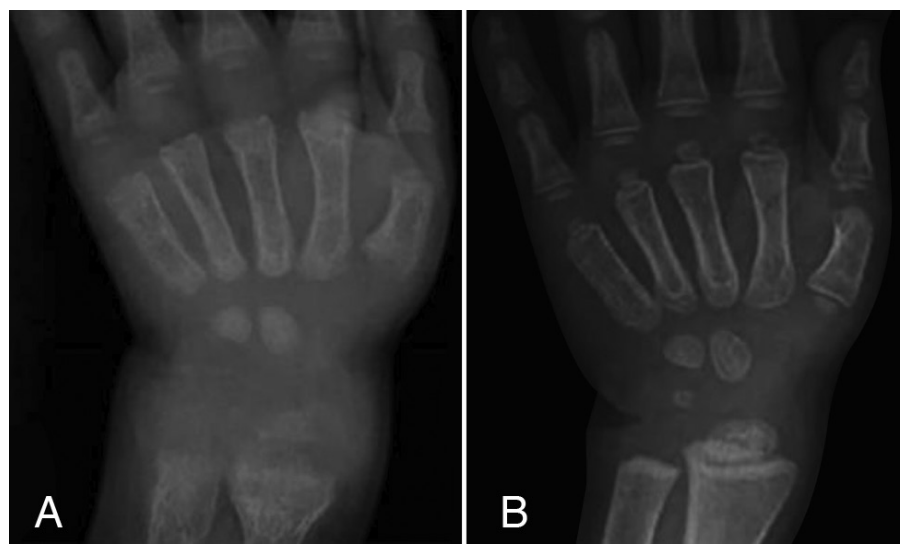

Figure 1. X-rays of this patient before $(A)$ and at the $6^{\text {th }}$ month of calcitriol treatment (B)

(A) Abnormal cupping, widening and fraying of the metaphyses consistent with rickets. (B) Recovery of cupping and fraying, and a provisional calcification zone suggesting healing rickets families had homozygous duplication mutation in exon 8 (1319_1325dupCCCACCC, Phe443Profs*24), which has been previously reported (Figure 2). A homozygous c. 1215 $+2 \mathrm{~T}>\mathrm{A}$ mutation in the splice donor site of intron-7 was found in one patient and one patient was found to have a homozygous mutation in exon 9 (C.1474 C > T).

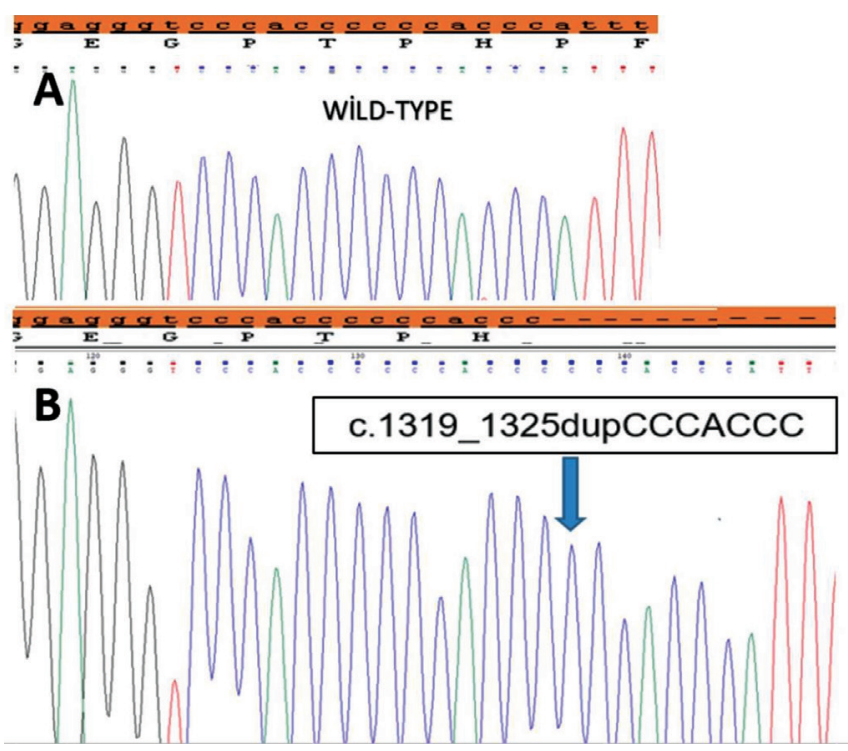

Figure 2. A) Wild type sequence of exon 8 in $C Y P 27 B 1$ gene. B) Sequencing analysis of the CYP27B1 gene exon 8 showing the homozygous mutation (1319_1325dupCCCACCC, Phe443Profs*24)

\begin{tabular}{|c|c|c|c|c|c|c|c|c|c|}
\hline Subjects & $\begin{array}{l}\text { Age } \\
\text { (months) }\end{array}$ & $\begin{array}{l}\text { Presenting } \\
\text { symptoms }\end{array}$ & $\begin{array}{l}\text { Height } \\
\text { SD }\end{array}$ & $\begin{array}{l}\mathrm{Ca} \mathrm{mg} / \mathrm{dL} \\
\mathrm{NR}: 9-11.5\end{array}$ & $\begin{array}{l}\text { P mg/dL } \\
\text { NR: 4-6.5 }\end{array}$ & $\begin{array}{l}\text { PTH } \mathrm{pg} / \mathrm{mL} \\
\text { NR: } 11-67\end{array}$ & $\begin{array}{l}\text { ALP IU/L } \\
\text { NR }<455\end{array}$ & $\begin{array}{l}25-\mathrm{OHD} \\
\mathrm{ng} / \mathrm{mL} \\
\mathrm{NR}>20\end{array}$ & $\begin{array}{l}\text { 1,25- } \mathrm{OH}_{2} \mathrm{D} \\
\mathrm{pg} / \mathrm{mL} \\
\mathrm{NR}: 20-153\end{array}$ \\
\hline 1.1 & 18 & $\begin{array}{l}\text { Bowed legs, growth } \\
\text { retardation }\end{array}$ & -2 & 8.0 & 2.3 & 441 & 2120 & 26 & 15 \\
\hline 1.2 & 36 & $\begin{array}{l}\text { Bowed legs, growth } \\
\text { retardation }\end{array}$ & -2.5 & 7.1 & 3.1 & 784 & 3100 & 64 & 10 \\
\hline 1.3 & 18 & $\begin{array}{l}\text { Bowed legs, growth } \\
\text { retardation }\end{array}$ & -2.1 & 6.2 & 2.8 & 980 & 1940 & 120 & 12 \\
\hline 2 & 9 & $\begin{array}{l}\text { O-bine deformity, } \\
\text { failure to thrive }\end{array}$ & -3.1 & 7.8 & 3.0 & 625 & 1445 & 45 & 6 \\
\hline 3 & 14 & Hypotonia & -4.7 & 8.4 & 2.2 & 972 & 3111 & 194 & 38 \\
\hline 4.1 & 6 & $\begin{array}{l}\text { History of VDDR } \\
\text { sibling }\end{array}$ & 0.28 & 8.0 & 2.9 & 546 & 1325 & 50 & 11 \\
\hline 4.2 & 7 & Inability to work & -1.06 & 8.9 & 2.1 & 423 & 1400 & 132 & 45 \\
\hline 5 & 14 & Growth retardation & -2.2 & 5.91 & 3.4 & 925 & 2531 & 41 & $<1.3$ \\
\hline 6 & 11 & $\begin{array}{l}\text { Hypocalcaemic } \\
\text { seizure }\end{array}$ & -0.55 & 6.7 & 3.6 & 467 & 651 & 89 & 15.4 \\
\hline 7 & 24 & Inability to walk & -2.1 & 8.7 & 2.3 & 1397 & 4479 & 18.7 & 21.5 \\
\hline 8 & 24 & $\begin{array}{l}\text { Elevated ALP, } \\
\text { inability to walk }\end{array}$ & -3.1 & 8.2 & 2 & 571 & 1001 & 135 & 5.5 \\
\hline
\end{tabular}

SD: standard deviation, Ca: calcium, P: phosphate, PTH: parathyroid hormone, ALP: alkaline phosphatase, NR: normal range, VDDR: vitamin D dependent rickets, 25-OHD: 25-hydroxylase, 1,25- $\mathrm{OH}_{2} \mathrm{D}$ : 1,25-dihydroxyvitamin D. 


\begin{tabular}{|c|c|c|c|c|c|}
\hline Family number & Exon/intron & DNA description & Zygosity & $\mathrm{CF}$ & $\mathrm{MO} / \mathrm{PO}$ \\
\hline 1.1 & Intron-1 & C. $195+2 \mathrm{~T}>\mathrm{G}$ & HM & Yes & Batman/Batman \\
\hline 1.2 & Intron-1 & C. $195+2 \mathrm{~T}>\mathrm{G}$ & HM & Yes & Batman/Batman \\
\hline 1.3 & Intron-1 & c. $195+2 \mathrm{~T}>\mathrm{G}$ & HM & Yes & Batman/Batman \\
\hline 2 & Intron-1 & c. $195+2 \mathrm{~T}>\mathrm{G}$ & HM & No & Batman/Batman \\
\hline 3 & Intron-1 & C. $195+2 \mathrm{~T}>\mathrm{G}$ & HM & No & Batman/Batman \\
\hline 4.1 & Intron-1 & C. $195+2 \mathrm{~T}>\mathrm{G} / \mathrm{C} .1215+2 \mathrm{~T}>\mathrm{A}$ & $\mathrm{CHT}$ & No & Batman/Bitlis \\
\hline 4.2 & Intron-1 & C. $195+2 \mathrm{~T}>\mathrm{G} / \mathrm{C} .1215+2 \mathrm{~T}>\mathrm{A}$ & $\mathrm{CHT}$ & No & Batman/Bitlis \\
\hline 5 & Exon 8 & p.Phe443Profs*24 (c.1319_1325dupCCCACCC) & HM & Yes & Erzurum/Erzurum \\
\hline 6 & Intron 7 & C. $1215+2 \mathrm{~T}>\mathrm{A}$ & HM & Yes & Mardin/Mardin \\
\hline 7 & Exon 9 & $\begin{array}{l}\text { c. } 1474 \mathrm{C}>\mathrm{T} \\
\text { p.R492W }\end{array}$ & HM & Yes & Mersin/Mersin \\
\hline 8 & Exon 8 & p.Phe443Profs*24 (c.1319_1325dupCCCACCC) & HM & Yes & Elazığ/Elazığ \\
\hline
\end{tabular}

\section{Discussion}

In the present study, we report the clinical, biochemical and genetic analysis of 11 patients with VDDR1A. We identified five previously reported mutations. The most prevalent mutation was the c. $195+2 \mathrm{~T}>\mathrm{G}$ splice donor site mutation. Five patients from two different families had this mutation as homozygous and two patients from the same family had hemizygous inheritance as a part of compound heterozygous mutation. Durmaz et al (19) reported this mutation for the first time in a Turkish patient. Currently the c. $195+2 \mathrm{~T}>\mathrm{G}$ homozygous mutation in intron- 1 is present in a total of 20 patients including the patients described herein, all reported from Turkey $(4,9,19)$. These patients were homozygous for the previously described splice donor site mutation c. 195 $+2 \mathrm{~T}>\mathrm{G}$, where a thiamine is substituted for a guanine in the second nucleotide of intron-1. Since this mutation is common in Turkish patients and has not been reported in other ethnic groups, it may be unique, representing a 'founder' or "common ancestor" effect, given the high rates of consanguinity. Although it has not been reported in other publications, all patients in the study by Tahir et al (9) were living in Diyarbakır or neighbouring provinces; all of our patients carrying that mutation were from Batman, which is geographically very close to Diyarbakır.

While Tahir et al (9) reported that patients with intron-1 mutation had a milder clinical presentation, Demir et al (4) reported that the most severe form of the disease occurred in a patient with intron-1 mutation thus the phenotype may be variable and a larger evidence base would be necessary to determine the genotype/phenotype relationship more clearly. We could not identify any relationship between genotype and phenotype although our series adds to the existing evidence. All patients in the literature who had an intron-1 mutation had delayed walking and bowed legs at admission. While four of our patients were also affected thus, another patient presented with hypotonia. Although 4 of 5 patients with intron- 1 mutation had a height below $-2 \mathrm{SD}$, patients with other mutations also had short stature.

We had only one patient presenting at the age of 11 months with a hypocalcaemic convulsion. Hypocalcaemic convulsion has also been reported rarely by other studies from Turkey. Tahir et al (9) reported hypocalcaemic convulsion in five of 22 patients; Demir et al (4) in 4 of 8 patients; and Durmaz et al (19) in two of seven patients. Kim et al (20) reported that 4 of their 10 patients presented with hypocalcaemic convulsion. Edouard et al (21) reported that the admission symptom was hypocalcaemic convulsion in 4 of 21 pediatric patients. Since these patients had blood calcium levels that were in the lower limit of the normal range, hypocalcemic convulsion was not frequently encountered.

The clinical presentations of patients with VDDR1 A could lead to a misdiagnosis of nutritional rickets or hypophosphatemic rickets, which can be differentiated from hypophosphatemic rickets by a high PTH level and from nutritional rickets by a normal 25-OHD level. The hypophosphatemia in VDDR1A is a result of elevated PTH and renal excretion of phosphate. The clinical and laboratory features of VDDR1A are very similar to nutritional rickets although the differential diagnosis can be made by a low or inappropriately normal 1, 25$\mathrm{OH}_{2} \mathrm{D}$ level and unresponsiveness to vitamin $\mathrm{D}$ treatment. In our study, six patients had also had long-term therapy 
with vitamin $\mathrm{D}$ because of an initial diagnosis of nutritional rickets and they had extremely high 25-OHD levels. Four patients had normal calcium levels and one of them had been followed with hypophosphatemic rickets. There are a few patients with normal $1,25-\mathrm{OH}_{2} \mathrm{D}$ levels diagnosed with VDDR1 $A$ in the literature $(4,8)$. In fact, the expected $1,25-\mathrm{OH}_{2} \mathrm{D}$ levels in $1 \alpha$-hydroxylase deficiency are low and inappropriately normal $1,25-\mathrm{OH}_{2} \mathrm{D}$ levels also indicate that the enzyme activity is insufficient. Recently, Nishikawa et al (22) reported that liver mitochondrial CYP27A1 can catalyse $1 \alpha$-hydroxylation of $25-\mathrm{OHD}$. A small increase in serum $1,25-\mathrm{OH}_{2} \mathrm{D}$ concentration has been observed in CYP27B1 knockout mice after being given high dietary vitamin $D$, suggesting a conversion from $25-\mathrm{OHD}$ to $1,25-\mathrm{OH}_{2} \mathrm{D}$ by a non-CYP27B1 enzyme. Three of eleven patients in our study had normal $1,25-\mathrm{OH}_{2} \mathrm{D}$ levels and there was a history of high dose vitamin $\mathrm{D}$ intake in two of these three patients. In these patients, conversion from 25-OHD to $1,25-\mathrm{OH}_{2} \mathrm{D}$ by a non-CYP27B1 enzyme may have contributed to the normal $1,25-\mathrm{OH}_{2} \mathrm{D}$ level.

Maternal $1,25-\mathrm{OH}_{2} \mathrm{D}$ does not cross the fetoplacental barrier $(21,23) \cdot 1,25-\mathrm{OH}_{2} \mathrm{D}$ increases $2-3$ fold in the first weeks of pregnancy when maternal 25-OHD crosses the placental barrier. The rise in circulating $1,25-\mathrm{OH}_{2} \mathrm{D}$ concentrations in the mother facilitates optimal in utero bone development by attaining a positive calcium balance (24). Edouard et al (21) reported that, unlike patients with severe vitamin $\mathrm{D}$ deficiency who can present within the first six months of life, none of the VDDR1A patients were symptomatic before the age of six months. Indeed, the infant who was diagnosed with VDDR1A at the age of one month had a low serum $1,25-\mathrm{OH}_{2} \mathrm{D}$ and a positive CYP27B1 sequencing result but did not have any clinical or radiological signs of rickets (21). This indicates that $1,25-\mathrm{OH}_{2} \mathrm{D}$ is not critical for mineral ion homeostasis and growth plate mineralization in the first months of life owing to in utero positive calcium balance in these patients. All patients in this study group were aged 6-months or older at admission.

Generally, a good response to treatment with alfacalcidol or calcitriol (10-400 $\mathrm{ng} / \mathrm{kg} /$ day) is expected in cases with VDDR1A $(4,21)$. Calcitriol dose was tailored based on biochemical and clinical findings. Edouard et al (21) indicated short and long-term outcomes of calcitriol treatment in their patients. They started calcitriol treatment at a dose of $1.0 \mu \mathrm{g} /$ day, given in two doses of $0.5 \mu \mathrm{g}$. Treatment with calcitriol resulted in the normalization of biochemical parameters within three months. The aims of the treatment were to achieve normocalcemia, to maintain PTH levels within normal limits and to avoid hypercalciuria. Our patients had not reached their final height and their treatment durations ranged between six months and seven years. Improvement of biochemical parameters occurred somewhat later than previously reported at between four and 12 months.

\section{Study Limitations}

The main limitation of our study is the relatively small number of patients.

\section{Conclusion}

Although VDDR1A is a rare disease, it is more common in Turkey where autosomal recessive disorders are common. In this study, we evaluated the genetic and clinical features of 11 patients with the diagnosis of VDDR 1 A. Intron-1 mutation was the most common mutation, as in the previous studies, and all patients carrying this mutation were from the same city of origin, suggesting a "founder" or a "common ancestor" effect. As it may be confused with nutritional rickets and hypophosphatemic rickets, genetic analysis is important for making a correct diagnosis. VDDR1 A should be considered when a patient with signs of rickets has a normal 25OHD level or when there is unresponsiveness to vitamin D treatment. We should emphasize that concentrations of $1,25-\mathrm{OH}_{2} \mathrm{D}$ levels can be within normal ranges in patients with VDDR1A and this may lead to diagnostic confusion.

\section{Ethics}

Ethics Committee Approval: The study was approved by the University of Health Sciences Ümraniye Training and Research Hospital Clinical Research Ethical Committee (approved number: 19/01/2018- 2926).

Informed Consent: Informed consent was obtained from patients and/or families.

Peer-review: Externally and internally peer-reviewed.

\section{Authorship Contributions}

Surgical and Medical Practices: Fatma Dursun, Bülent Hacihamdioğlu, Concept: Fatma Dursun, Heves Kırmızıbekmez, Ece Keskin, Design: Fatma Dursun, Bülent Hacıhamdioğlu, Heves Kırmızıbekmez, Ece Keskin, Data Collection or Processing: Fatma Dursun, Bülent Hacıhamdioğlu, Heves Kırmızıbekmez, Ece Keskin, Gamze Özgürhan, Analysis or Interpretation: Fatma Dursun, Bülent Hacıhamdioğlu, Heves Kırmızıbekmez, Ece Keskin, Gamze Özgürhan, Literature Search: Fatma Dursun, Heves Kırmızıbekmez, Ece Keskin, Gamze Özgürhan, Bülent Hacıhamdioğlu, Writing: Fatma Dursun, Heves Kırmızıbekmez, Ece Keskin, Bülent Hacıhamdioğlu. 
Financial Disclosure: The authors declared that this study received no financial support.

\section{References}

1. Holick MF. Vitamin D deficiency. N Engl J Med 2007;357:266-281.

2. Alzahrani AS, Zou M, Baitei EY, Alsshaikh OM, Al-Rijjal RA, Meyer BF, Shi Y. A novel G102E mutation of CYP27B1 in a large family with vitamin D-dependent rickets type 1. J Clin Endocrinol Metab 2010;95:41764183. Epub 2010 Jun 9

3. Miller WL, Portale AA. Vitamin D biosynthesis and vitamin D 1 alphahydroxylase deficiency. Endocr Dev 2003;6:156-174.

4. Demir K, Kattan WE, Zou M, Durmaz E, BinEssa H, Nalbantoğlu Ö, Al-Rijjal RA, Meyer B, Özkan B, Shi Y. Novel CYB27B1 Gene Mutations in Patients with Vitamin D-Dependent Rickets Type 1A. PloS One 2015;10:e0131376.

5. Malloy PJ, Feldman D. Genetic disorders and defects in vitamin D action. Rheum Dis Clin North Am 2012;38:93-106. Epub 2012 Apr 12

6. Cheng JB, Levine MA, Bell NH, Mangelsdorf DJ, Russel DW. Genetic evidence that the human CYP2R1 enzyme is a key vitamin D 25hydroxylase. Proc Natl Acad Sci 2004;101:7711-7715. Epub 2004 May 5

7. Babiker AM, Al Gadi I, Al-Jurayyan NA, Al Nemri AM, Al Haboob AA, Al Boukai AA, Al Zahrani A, Habib HA. A novel pathogenic mutation of the CYP27B1 gene in a patient with vitamin D-dependent rickets type 1: a case report. BMC Res Notes 2014;7:783.

8. Acar S, Demir K, Shi Y. Genetic causes of rickets. J Clin Res Pediatr Endocrinol 2017;9(Suppl 2):88-105. Epub 2017 Dec 27

9. Tahir S, Demirbilek H, Ozbek MN, Baran RT Tanriverdi S, Hussain K. Genotype and Phenotype Characteristics in 22 Patients with Vitamin D-Dependent Rickets Type I. Horm Res Paediatr 2016;85:309-317. Epub 2016 Mar 17.

10. Fu GK, Lin D, Zhang MY, Bikle DD, Shackleton CH, Miller WL, Portale AA. Cloning of human 25-hydroxyvitamin D- 1 alpha-hydroxylase and mutations causing vitamin D-dependent rickets type I. Mol Endocrinol 1997;11:1961-1970

11. St-arnaud R, Messerlian S, Moir JM, Omdahl JL, Glorieux FH. The 25-hydroxyvitamin D1-alpha-hydroxylase gene maps to the pseudovitamin D-deficiency rickets (PDDR) disease locus. J Bone Miner Res 1997;12:1552-1559.

12. Monkowa T, Yoshida T, Wakino S, Anazawa H, Deluca HF, Suda T, Hayashi M, Saruta T. Molecular cloning of cDNA and genomic DNA for human 25-hydroxyvitamin D3 1 alpha-hydroxylase. Biochem Biophys Res Commun 1997;239:527-533.

13. Kim CJ. Vitamin D dependent rickets type I. Korean J Pediatr 2011;54:51-54. Epub 2011 Feb 28

14. Stenson PD, Ball EV, Mort M, Phillips AD, Shiel JA, Thomas NS, Abeysinghe S, Krawczak M, Cooper DN. Human Gene Mutation Database (HGMD): 2003 update. Hum Mut 2003;21:577-581.

15. Shaw NJ. Vitamin D deficiency rickets. Endocr Dev 2003;6:93-104.

16. Schwarz JM, Rödelsperger C, Schuelke M, Seelow D. Mutation Taster evaluates disease-causing potential of sequence alterations. Nat Methods 2010;7:575-576

17. Adzhubei IA, Schmidt S, Peshkin L, Ramensky VE, Gerasimova A, Bork P, Kondrashov AS, Sunyaev SR. A method and server for predicting damaging missense mutations. Nat Methods 2010;7:248-249.

18. Kumar P, Henikoff S, Ng PC. Predicting the effects of coding nonsynonymous variants on protein function using the SIFT algorithm. Nat Protoc 2009;4:1073-1081. Epub 2009 Jun 25

19. Durmaz E, Zou M, Al-Rijjal RA, Bircan I, Akcurin S, Meyer B, Shi Y. Clinical and genetic analysis of patients with vitamin D-dependent rickets type 1A. Clin Endocrinol (Oxf) 2012;77:363-369.

20. Kim JC, Kaplan LE, Perward F, Huang N, Sharma A, Choi Y, Miller WL, Portale AA. Vitamin D 1alpha-hydroxylase gene mutations in patients with 1 alpha-hydroxylase deficiency. J Clin Endocrinol Metab 2007;92:3177-3182. Epub 2007 May 8

21. Edouard T, Alos N, Chabot G, Roughley P, Glorieux FH, Rauch F. Shortand long-term outcome of patients with pseudo-vitamin D deficiency rickets treated with calcitriol. J Clin Endocrinol Metab 2011;96:82-89. Epub 2010 Oct 6

22. Nishikawa M, Yasuda K, Takamatsu M, Abe K, Nakagawa K, Tsugawa N, Hirota Y, Tanaka K, Yamashita S, Ikushiro S, Suda T, Okano T, Sakaki T. Generation of 1,25-dihydroxyvitamin D3 in cyp27b1knockout mice by treatment with 25-hydroxyvitamin D3 rescued their rachitic phenotypes. J Steroid Biochem Mol Biol 2019;185:71-79. Epub 2018 Jul 18

23. Kovacs CS. Vitamin D in pregnancy and lactation: maternal, fetal, and neonatal outcomes from human and animal studies. Am J Clin Nutr 2008;88:520-528

24. Karras SN, Wagner CL, Castracane VD. Understanding vitamin D metabolism in pregnancy: from physiology to pathophysiology and clinical outcomes. Metabolism 2018;86:112-123. Epub 2017 Oct 21 